\title{
Increased expression of CCAAT/enhancer binding protein B correlates with prognosis in glioma patients
}

\author{
JUMPEI HOMMA, RYUYA YAMANAKA, NAOKI YAJIMA, NAOTO TSUCHIYA, \\ NOBUYUKI GENKAI, MASAKAZU SANO and RYUICHI TANAKA
}

Department of Neurosurgery, Brain Research Institute, Niigata University, 1-757 Asahimachi-dori, Niigata 951-8585, Japan

Received July 12, 2005; Accepted August 29, 2005

\begin{abstract}
C/EBP B (CCAAT/enhancer binding protein $\beta)$ is a transcriptional factor that belongs to the basic region-leucine zipper class DNA-binding proteins and plays a role in cell differentiation and inflammatory reactions. Although high tissue levels of inflammatory cytokines, such as interleukin (IL)-6, IL- 8 and transforming growth factor- $\beta$, have been observed in glioma patients, the mechanisms underlying this phenomenon remain to be elucidated. C/EBP $B$ induces a variety of cytokines and thus may play a role in the pathogenesis of glioma. In this study, we investigated the relationship between $\mathrm{C} / \mathrm{EBP} \beta$ expression, tumor histology, and prognosis in glioma. The expression of C/EBP $\beta$ mRNA was examined with quantitative real-time PCR and protein expression was examined with immunohistochemical techniques in 47 glioma tissue samples. Expression of C/EBP B mRNA and protein was markedly increased in high grade glioma compared with low grade glioma. Patients whose expression of $\mathrm{C} / \mathrm{EBP} \beta$ mRNA and protein in tumor tissue was lower survived longer than those whose expressions were higher. In vitro, C/EBP B siRNA inhibited glioma cell proliferation and invasion. Moreover, IL-8 production by glioma cells was inhibited by C/EBP $\beta$ siRNA transfection. These data suggest that increased expression of $\mathrm{C} / \mathrm{EBP} \beta$ may contribute to the promotion of tumor invasiveness and progression. The data imply that the comparison of C/EBP $B$ expression could be a prognostic marker for patients with glioma.
\end{abstract}

Correspondence to: Dr Ryuya Yamanaka, Department of Neurosurgery, Brain Research Institute, Niigata University, Asahimachidori 1-757, Niigata City 951-8585, Japan

E-mail: ryaman@bri.niigata-u.ac.jp

Abbreviations: C/EBP, CCAAT/enhancer binding protein; IL, interleukin; MEM, minimum essential medium; MMP, matrix metalloproteinase; PBS, phosphate-buffered saline

Key words: CCAAT/enhancer binding protein $ß$, glioma, interleukin-8, siRNA

\section{Introduction}

Glioblastoma is an ordinary solid tumor with poor prognosis; even with recent advances in cancer diagnostic methodology and treatment, the prognosis of glioblastoma worldwide has not improved $(1,2)$. This poor prognosis is attributable to the difficulty of early detection and a high recurrence rate during post-initial treatment observation periods. This is at least partly due to the lack of reliable tumor markers for, and molecular targets against, glioblastomas.

The CCAAT/enhancer binding proteins (C/EBPs) comprise a family of structurally related transcription factors which play a role in normal tissue development, cellular proliferation and differentiation (3). The typical C/EBP protein consists of a $\mathrm{N}$-terminal activation domain, a basic DNA binding region, and a leucine zipper dimerization domain that enables dimer formation with other $\mathrm{C} / \mathrm{EBP}$ proteins as well as with transcriptional factors of the AP-1, NF- $\kappa \mathrm{B}$ (3-5). All of these distinct interactions result in the differential transcriptional activity of the $\mathrm{C} / \mathrm{EBP}$ isoforms. At present, six members (C/EBP $\alpha$, $-\beta,-\gamma,-\delta,-\varepsilon$, and $-\zeta)$ with different tissue-specific expression patterns have been characterized $(3,6-14)$. C/EBPs exert pleiotropic effects based on tissue- and stage-specific gene expression, alternative translation of various protein isoforms, interaction with other transcription factors, and variable DNA-binding specificities. C/EBPs are reported to play an important role in the control of, and as essential transducers of intracellular responses to extracellular control signals (15). The expression of these proteins is influenced by a variety of external stimuli such as growth factors, hormones or cytokines $(3,16)$. In addition, by using different start codons, the translation of C/EBPs results in two or more protein products which differ in their biological activities $(3,12,17,18)$. As an additional level of regulation, posttranslational phosphorylation influences DNA binding and transactivation properties $(3,19)$.

$\mathrm{C} / \mathrm{EBP} \mathrm{B}$ is ubiquitously expressed and is induced by such inflammatory cytokines as IL-1, IL-6 and TNF- $\alpha$ (20). C/EBP $\beta$ was originally identified and named NF-IL-6 as a DNA-binding protein responsible for IL-1-stimulated IL-6 induction (8). It was recently reported that $\mathrm{C} / \mathrm{EBP} \beta$ induces IL-8 and TNF- $\alpha$ expression $(21,22)$. IL- 8 , an angiogenic cytokine secreted from glioma cells, is thought to be a causative cytokine of hypervascularity in malignant glioma (23). Thus, $\mathrm{C} / \mathrm{EBP}$ B may play a role in the tumor progression of glioma. 
Table I. Patient characteristics.

\begin{tabular}{lccr}
\hline $\begin{array}{l}\text { Pathological } \\
\text { diagnosis }\end{array}$ & $\begin{array}{c}\text { No. of } \\
\text { cases }\end{array}$ & $\begin{array}{c}\text { Gender } \\
\text { (male/female) }\end{array}$ & \multicolumn{1}{c}{$\begin{array}{c}\text { Age } \\
\text { (mean } \pm \text { SD) }\end{array}$} \\
\hline Astrocytoma & 9 & $4 / 5$ & $28.0 \pm 18.0$ \\
$\begin{array}{l}\text { Anaplastic } \\
\text { astrocytoma }\end{array}$ & 11 & $5 / 6$ & $38.6 \pm 12.5$ \\
Glioblastoma & 27 & $17 / 10$ & $52.0 \pm 16.9$ \\
Total & 47 & $26 / 21$ & $44.23 \pm 18.6$ \\
\hline
\end{tabular}

An increased expression of $\mathrm{C} / \mathrm{EBP} \beta$ is reported in breast cancer (24), ovarian cancer (25), colorectal cancer (26) and renal cell carcinoma (27). In contrast, downregulated expression has been reported in squamous cell carcinoma (28) and hepatocellular carcinoma (29). In this study, we investigated the expression of C/EBP $\beta$ in 47 glioma tissue specimens of different grades, and whether or not an increased expression of C/EBP $\beta$ correlated with patient prognosis.

\section{Materials and methods}

Cell lines and culture. All glioma cell lines were cultured in MEM (Nissui Pharmaceutical Inc., Tokyo, Japan) supplemented with 10\% FBS (fetal bovine serum). The T98G, GI-1 and U251 cell lines were purchased from Cell Bank, RIKEN BioResource Center (Tsukuba, Japan).

Patient characteristics and tissue samples. A total of 47 glioma tissue samples were investigated that were surgically removed in the Department of Neurosurgery, Brain Research Institute, Niigata University. Tumor tissue and normal brain tissue specimens were dissected and immediately frozen at $-80^{\circ} \mathrm{C}$. The patient data are shown in Table I. After surgical resection of their tumor, patients with high grade glioma had a course of external beam radiation therapy (standard dose, $40 \mathrm{~Gy}$ to the tumor with 3-cm margins, $20 \mathrm{~Gy}$ boost to the whole brain) and nitrosourea based chemotherapy during the course of the disease. Survival was determined from the date of diagnosis to death or last visit. These diagnoses were based on the World Health Organization (WHO) criteria (30). This study was approved by the Ethics Committee of Niigata University. Informed consent was obtained from all patients.

Extraction of proteins. Stored samples were crushed in liquid nitrogen and homogenized in RIPA buffer [50 mM Tris- $\mathrm{HCl}$ (pH 7.4), 1\% Nonidnet P-40, $0.25 \%$ desoxycholate, $150 \mathrm{mM}$ $\mathrm{NaCl}, 1 \mathrm{mM}$ EGTA, and $0.2 \%$ sodium dodecyl sulfate (SDS)] containing the following kinase, phosphatase, and protease inhibitors: $1 \mathrm{mM} \mathrm{NaVO}_{3}, 1 \mathrm{mM} \mathrm{NaF}, 1 \mathrm{mM} \mathrm{Na}_{2} \mathrm{MoO}_{4}, 10 \mathrm{nM}$ okadaic acid, $1 \mu \mathrm{g} / \mathrm{ml}$ benzamide and aprotinin (all Sigma, Tokyo, Japan) and incubated on ice for $15 \mathrm{~min}$. The supernatants were taken and stored at $-80^{\circ} \mathrm{C}$.

IL-8 determination by ELISA. The cells were cultured in triplicate in MEM containing 10\% FBS medium for $48 \mathrm{~h}$.
Cell-free culture supernatants were analyzed for IL- 8 protein content by ELISA using a commercial kit according to the manufacturer's instructions (R\&D Systems, Minneapolis, MN).

Immunoblotting. The extracted protein $(100 \mu \mathrm{g})$ with sample buffer containing 2-mercaptoethanol was separated on 5-20\% SDS-PAGE (Bio-Rad Laboratories, Hercules, CA) and transferred to a nitrocellulose membrane (Bio-Rad Laboratories). The membrane was incubated with $5 \%$ skim milk in Trisbuffered saline overnight followed by incubation with primary antibodies for C/EBP B (Santa Cruz Biotechnology, Santa Cruz, CA). Anti- $\beta$-actin mouse monoclonal antibody (Santa Cruz Biotechnology) was used as an internal control. Immunodetection was performed using a horseradish peroxidase detection system with ECL plus (Amersham, Tokyo).

Immunohistochemistry. Five-micron sections from formalinfixed, paraffin-embedded tissue specimens were deparaffinized in xylene and dehydrated in graded ethanols, followed by PBS. Antigen was retrieved by incubation at $121^{\circ} \mathrm{C}$ for $10 \mathrm{~min}$ in $10 \mathrm{mM}$ sodium citrate $(\mathrm{pH}$ 6.0) followed by an incubation with $0.3 \% \mathrm{H}_{2} \mathrm{O}_{2}$ to quench the endogenous peroxidase activity. The slides were blocked in $10 \%$ goat serum and incubated with rabbit polyclonal anti-C/EBP $\beta$ antibody (dilution 1:50; Santa Cruz Biotechnology) for $24 \mathrm{~h}$ at $4^{\circ} \mathrm{C}$. After washing, the slides were incubated with an avidin-biotin-peroxidase system (Vectasin ELITE ABC kit, Vector Laboratories, Burlingame, CA). Finally, the sections were exposed for 10-20 min to $0.01 \%$ 3,3-diaminobenzidine (DAB) (Sigma) and PBS containing $0.01 \%$ hydrogen peroxide. A total of $\geq 500$ tumor cells were examined at an original magnification of x400 by light microscopy, and the intensity of positive cells was recorded for each immunostained specimen. At the time, observers were blind as to case numbers. The expression of C/EBP $B$ was evaluated by assigning an immunohistochemical score, defined as the intensity ( 0 , none; 1 , weak; 2 , moderate; 3 , strong) of the expression.

RNA isolation and quantitative PCR. Total RNA was isolated with Isogen (Nippongene, Toyama, Japan) from the frozen samples. First-strand cDNA was prepared with RNA from the specimens, oligo(dT) primers and reverse transcriptase (SuperScript II RNase H, Life Technologies, Grand Island, NY) according to the manufacturer's instruction. Quantitative PCR was performed by using real-time PCR with a LightCycler (Idaho Technology, Salt Lake City, UT). PCR reagents contained 1X LightCycler DNA Master SYBR Green I (Roche Molecular Biochemicals, Mannheim, Germany), $0.5 \mu \mathrm{M}$ of each primer, $3 \mathrm{mM} \mathrm{MgCl}_{2}$, and $2 \mu \mathrm{l}$ of cDNA template. PCR conditions were as follows: one cycle of denaturing at $95^{\circ} \mathrm{C}$ for $10 \mathrm{~min}$, followed by 40 cycles of $95^{\circ} \mathrm{C}$ for $15 \mathrm{sec}, 55^{\circ} \mathrm{C}$ for $5 \mathrm{sec}$, and $72^{\circ} \mathrm{C}$ for $10 \mathrm{sec}$. The $195 \mathrm{bp}$ reaction product was then subjected to a post-PCR melting cycle. The intensity of fluorescence was calculated at each cycle, and the standard curve was constructed with 3-fold serial dilutions of cDNA obtained from glioma cell lines. The primer sequences for PCR amplification were as follows: C/EBP ß sense, 5'-ACAGCGACGAGTACAAGATCC-3'; and $\mathrm{C} / \mathrm{EBP} \beta$ antisense, 5'-GCAGCTGCTTGAACAAGTT CC-3'. 
siRNA treatment and cell proliferation assay. Specific siRNA directed against human C/EBP $B$ was purchased from Santa Cruz Biotechnology. The siRNAs were introduced into glioma cell lines by cytofectin-mediated transfection according to the manufacturer's instruction (Qiagen, Tokyo). Cells were cultured in 96-well plates in $100 \mu 1$ of serum-enriched medium. When $80 \%$ confluence was reached, $25 \mu 1$ of $100 \mathrm{nM}$ siRNA in cytofectin was added drop-wise to the cell culture. The number of viable cells was evaluated at $48 \mathrm{~h}$ of culture by incubation with Tetra color one (Seikagaku Co., Tokyo) and the values obtained were compared with those of controls. Control experiments were done with Cy3-labeled siRNA (Qiagen) directed against an unrelated mRNA (Luciferase; siRNA $_{\text {LUC }}$ : Qiagen). Transfection efficiency was confirmed with Cy3-labeled siRNA $\mathrm{LUC}_{\text {in }}$ in ach assay. All proliferation experiments were repeated as independent experiments at least twice. The results represent the mean \pm standard deviation (SD) of two independent experiments.

Cell invasion of Matrigel. A transwell with an $8 \mu \mathrm{m}$ diameter pore membrane (Becton-Dickinson, Tokyo, Japan) was coated with $500 \mu \mathrm{l}$ of Matrigel (Becton-Dickinson) at $100 \mu \mathrm{g} / \mathrm{ml}$. Cells were left untreated, treated with control, and C/EBP B siRNA, transfected as described above. After $24 \mathrm{~h}$ of incubation, the cells were detached with cell dissociation solution (Sigma), washed twice with PBS, and resuspended in MEM containing $10 \%$ FBS. In the case of the siRNA, this corresponds to a second transfection $24 \mathrm{~h}$ after the first. In each case, $2 \times 10^{5}$ cells were seeded into the upper, Matrigelcoated chamber of the Transwell. The lower chamber was filled with MEM with $10 \%$ FBS. After $24 \mathrm{~h}$ of incubation at $37^{\circ} \mathrm{C}$, the non-imigrated cells in the upper chamber were gently detached by scraping, and the adherent cells present on the lower surface of each insert were stained by Giemsa; 10 fields were counted by light microscopy at x200 magnification. Results were calculated with reference to control values observed after incubation in untreated control for control and C/EBP $\beta$ siRNA.

Statistics. The differences in the C/EBP $B$ expression between the subgroups of glioma were tested for statistical significance using the Mann-Whitney U test. Statistical significance was determined at the $\mathrm{P}<0.05$ level. The survival curves were estimated according to the method of Kaplan and Meier and the curves were compared using the generalized Wilcoxon's test. The log-rank test was used to assess the strength of the association between survival time and single variables corresponding to factors thought to be prognostic for survival. Survival was determined from the date of diagnosis to death or last visit.

\section{Results}

Immunohistochemical analysis of $C / E B P \beta$ expression in glioma tissue. Immunohistochemistry was used to detect the localization of $\mathrm{C} / \mathrm{EBP} \beta$ proteins. The immunostaining pattern of glioma tissue is shown in Fig. 1. The C/EBP $B$ expression occurred in the nucleus of the tumor, showing activated transcription factors translocated into the nucleus. We analyzed 25 available specimens and the correlation was investigated

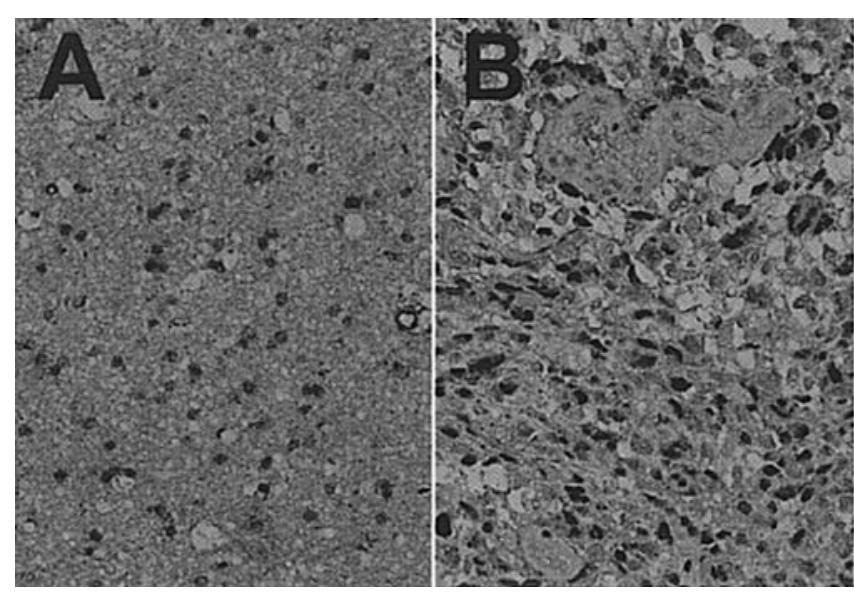

Figure 1. Representative immunohistochemical staining pattern of anti-C/ EBP B. (A) Astrocytoma classified as showing low C/EBP ß expression. (B) Glioblastoma multiforme classified as showing high $\mathrm{C} / \mathrm{EBP} \mathrm{B}$ expression. Magnification is $\mathrm{x} 200$.

Table II. Correlation of immunohistochemical pattern and pathological diagnosis.

\begin{tabular}{lcccc}
\hline & 0: none & 1: weak & 2: moderate & 3: strong \\
\hline Astrocytoma & 0 & 3 & 3 & 0 \\
$\begin{array}{l}\text { Anaplastic } \\
\text { astrocytoma }\end{array}$ & 2 & 2 & 2 & 0 \\
Glioblastoma & 1 & 2 & 7 & 3 \\
\hline
\end{tabular}

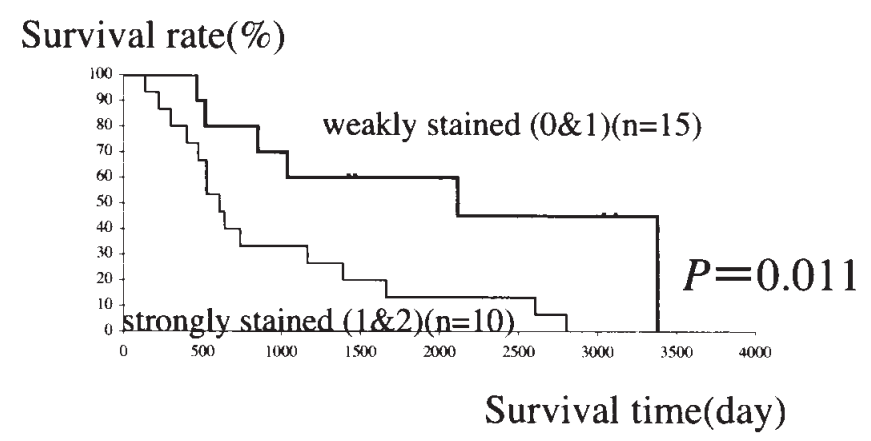

Figure 2. C/EBP $B$ protein expression and patient survival. Kaplan-Meier survival curves for patients who had undergone surgical resection of glioma tissue, stratified according to the level of $\mathrm{C} / \mathrm{EBP} \beta$ expression in their tumors. Comparison of protein expression and overall survival of patients with glioma (low C/EBP B staining, 0-1 score; high C/EBP B staining, 2-3 score; log-rank test, $\mathrm{P}=0.011$ ).

between the C/EBP $\beta$ staining, patient survival, and histological grading. Glioblastoma patients (13 cases) showed strong staining in comparison with grade 2 and 3 patients (12 cases) (Table II, $\mathrm{P}=0.045$ ). When comparing the high $\mathrm{C} / \mathrm{EBP}$ $\beta$ group with the low $\mathrm{C} / \mathrm{EBP} \beta$ group, increased $\mathrm{C} / \mathrm{EBP} \beta$ expression correlated with patient survival (log-rank test, $\mathrm{P}=0.011$; Fig. 2). 


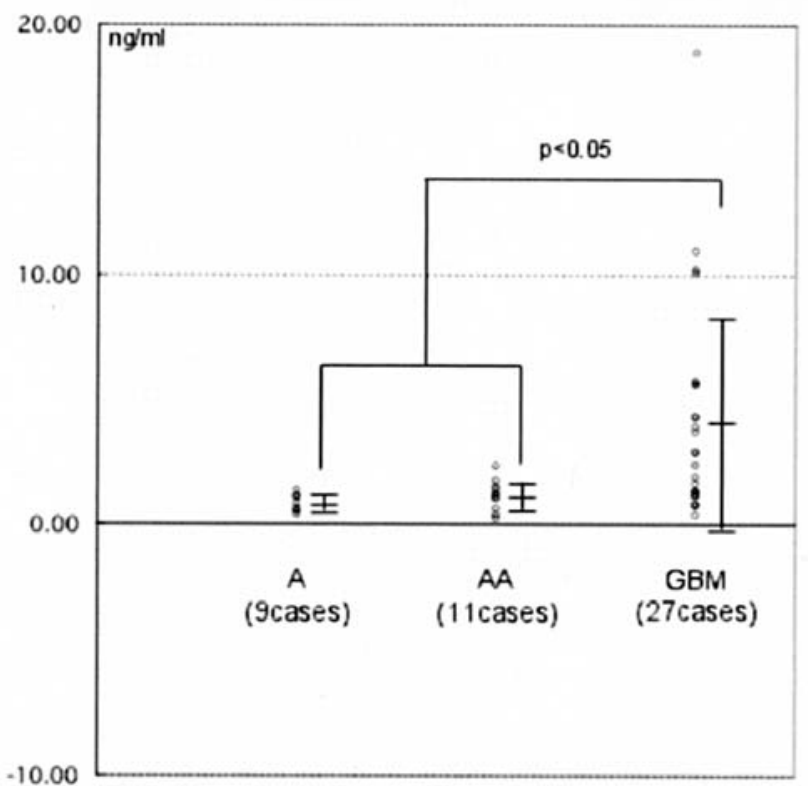

Figure 3. C/EBP $\beta$ gene expression compared to histological grading. High expression of $\mathrm{C} / \mathrm{EBP} \beta \mathrm{mRNA}$ was significantly associated with glioblastoma multiforme $(\mathrm{GBM})$ compared to astrocytoma (A) and anaplastic astrocytoma (AA) $(\mathrm{P}<0.05)$

Increased $C / E B P \beta$ gene expression in glioma correlates with the prognosis of the patients. We compared the expression level of the C/EBP $B$ genes in 47 samples with quantitative real-time PCR. C/EBP $B$ gene expression was compared with histological grading. High expression of C/EBP $B$ mRNA was significantly associated with glioblastoma multiforme (GBM) compared to astrocytoma (A) and anaplastic astrocytoma (AA) (Fig. 3, $\mathrm{P}=0.027$ ). The survival curves of the patients, grouped according to the level of C/EBP $B$ gene expression in their tumors, are shown in Fig. 4. The high $\mathrm{C} / \mathrm{EBP}$ B expression group $(>1.5 \mathrm{ng} / \mathrm{ml})$ had a significantly poorer prognosis than the low $\mathrm{C} / \mathrm{EBP} \mathrm{B}$ expression group $(<1.5 \mathrm{ng} / \mathrm{ml})($ log-rank test, $\mathrm{P}=0.043)$.

Glioma cell proliferation and invasion are inhibited by antiC/EBP $\beta$ siRNA transfection. C/EBP $\beta$ overexpression was linked with the aggressiveness of the glioma in our analysis. In order to determine whether down-regulation of endogenous C/EBP $\beta$ would suppress the proliferation and invasive behavior of glioma, we synthesized siRNAs that, when transfected into cells, targeting C/EBP $\beta \mathrm{mRNA}$ for degradation, thus reducing the expression of the $\mathrm{C} / \mathrm{EBP} B$ protein. We analyzed the efficacy of the siRNA-mediated inhibition of C/EBP 3 synthesis in U251, GI-1 and T98G cells by Western blotting. Because the results obtained were virtually identical in the three cell types, only one is presented here. As shown in Fig. 5A, when U251 cells were transfected with the corresponding siRNA, C/EBP $B$ proteins were downregulated $48 \mathrm{~h}$ later. Furthermore, $\beta$-actin protein levels, which serve as a control, were not modified by exposure to these siRNAs. Finally, transfection with a related control siRNA also failed to modify C/EBP $B$ protein expression.

After transfection with anti-C/EBP 3 siRNA, U251 cell counts in the ensuing $48 \mathrm{~h}$ were approximately $70 \%$ of

\section{Survival rate $(\%)$}

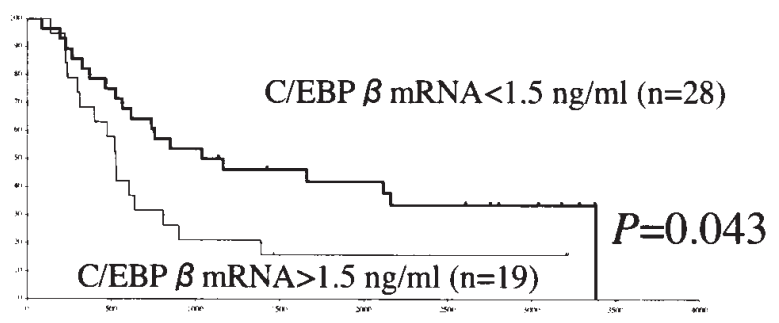

Survival time(day)

Figure 4. C/EBP ß mRNA expression and patient survival. Kaplan-Meier survival curves for patients who had undergone surgical resection of glioma tissue, stratified according to the level of expression of $\mathrm{C} / \mathrm{EBP} B$ in their tumors. Comparison of mRNA expression and overall survival of patients with glioma (low C/EBP $\beta$ mRNA, 0-1.5 ng/ml; high C/EBP $\beta$ mRNA, $\geq 1.5 \mathrm{ng} / \mathrm{ml}$ are detected; log-rank test, $\mathrm{P}=0.043$ ).

untreated or control-siRNA-treated cells during this same period of time (Fig. 5B, $\mathrm{P}<0.05$ ). Cell proliferation was significantly suppressed by siRNA against $\mathrm{C} / \mathrm{EBP} \beta$, as reflected in the observed reduction of protein expression.

For the invasion assays, the transfectants were seeded onto Matrigel-coated invasion chambers and incubated for $24 \mathrm{~h}$ and the total number of cells on the underside of each filter was determined. As shown in Fig. 5C, transfections of U251 cells with anti-C/EBP $\beta$ siRNA inhibited cell invasion through the Matrigel by $>80 \%$, whereas the control siRNA had no effect $(\mathrm{P}<0.01)$. Invading cells were significantly suppressed by siRNA against $\mathrm{C} / \mathrm{EBP} \beta$, as reflected in the observed reduction of protein expression.

IL-8 secretion on glioma cell lines. IL-8 secretion was determined by ELISA. IL-8 production was detected in T98G, U251 and GI- 1 cells by $100 \mathrm{IU} / \mathrm{ml}$ of IL-1 B stimulation after 24-48 h. IL-8 production was significantly suppressed by siRNA against $\mathrm{C} / \mathrm{EBP} \beta$, as reflected in the observed reduction of IL-8 production (Fig. 6, $\mathrm{P}=0.0073$ ).

\section{Discussion}

Malignant gliomas are the most common primary brain tumors and generally have very poor prognosis. Glioblastoma multiforme, pathologically the most aggressive form, has a median survival time of just 9-12 months $(1,2)$. Advances in the basic knowledge of cancer biology, as well as surgical techniques, chemotherapy and radiotherapy, have led to little improvement in survival rates for glioblastoma multiforme (31). There is thus a need to venture along previously unexplored avenues in order to devise more effective therapeutic approaches, to reveal more clearly the biological features of glioblastoma, and to discover a novel target molecule.

Cytokine secretion has been suggested to be related with the clinical features of glioma, such as positive inflammatory reactions and hypervascularity (23). IL-6, IL-8 and TGF- 3 are the most frequently detected cytokines in glioma (23). 


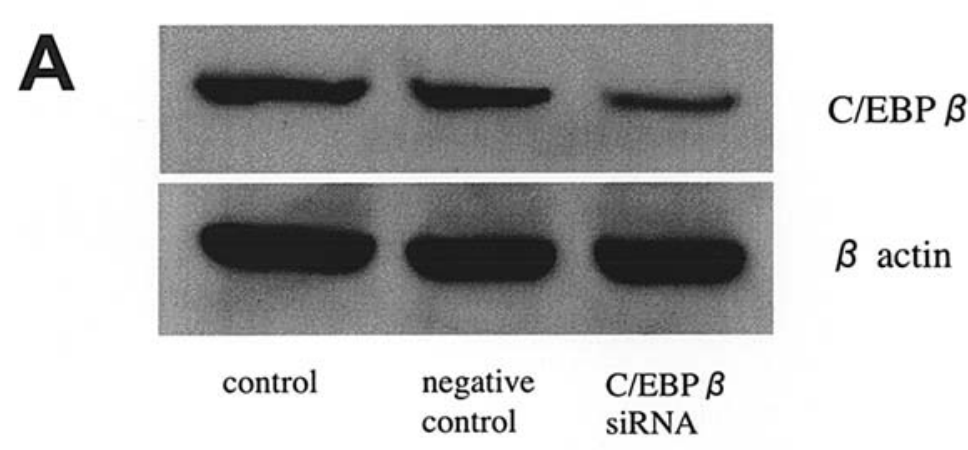

\section{B}

Cell growth(\%)

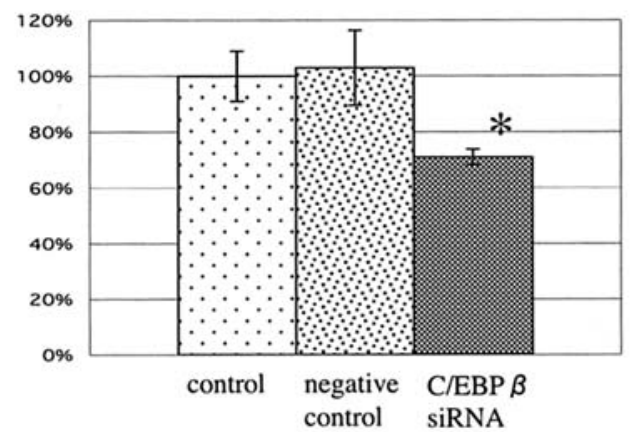

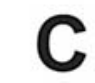

Cells /field

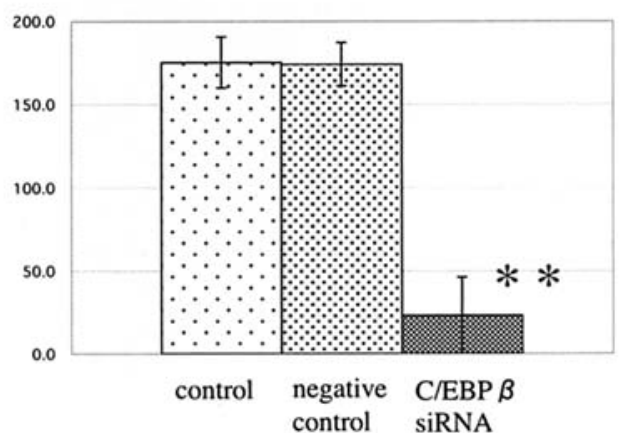

Figure 5. Effects of C/EBP $\beta$ knockdown by RNA interference on the proliferation and invasiveness of human glioma cell lines. U251 cells were transiently transfected with short interfering RNAs and subjected to Western blot analysis, MTT assay or Matrigel invasion assays. (A) Reduction of C/EBP $\beta$ protein expression by siRNA against C/EBP $B$ was determined by Western blot analysis. Transfection with C/EBP $\beta$ siRNA significantly reduced C/EBP $\beta$, whereas transfection with a siRNA targeted to an unrelated mRNA had no effect on C/EBP $\beta$ expression. (B) Cell proliferation assay. Cells were cultured in 96-well plates in $100 \mu 1$ of serum-enriched medium. When $80 \%$ confluence was reached, $25 \mu 1$ of $100 \mathrm{nM}$ siRNA in cytofectin was added drop wise. The number of viable cells was evaluated at $48 \mathrm{~h}$ of culture by incubation with Tetra color one and the values obtained were compared with those of controls. After transfection with anti-C/EBP 3 siRNA, U251 cell counts in the ensuing $48 \mathrm{~h}$ were approximately $70 \%$ of untreated or control-siRNA-treated cells during this same period of time. ${ }^{*} \mathrm{P}<0.05$ compared with both control groups. (C) For the invasion assays, the transfectants were seeded onto Matrigel-coated invasion chambers and incubated for $24 \mathrm{~h}$ and total number of cells on the underside of each filter was determined. Invading cells were significantly suppressed by siRNA against $\mathrm{C} / \mathrm{EBP} \beta$, as reflected in the observed reduction of protein expression. ${ }^{* *} \mathrm{P}<0.01$ compared with both control groups.

\section{$\mathrm{ng} / \mathrm{ml}$}

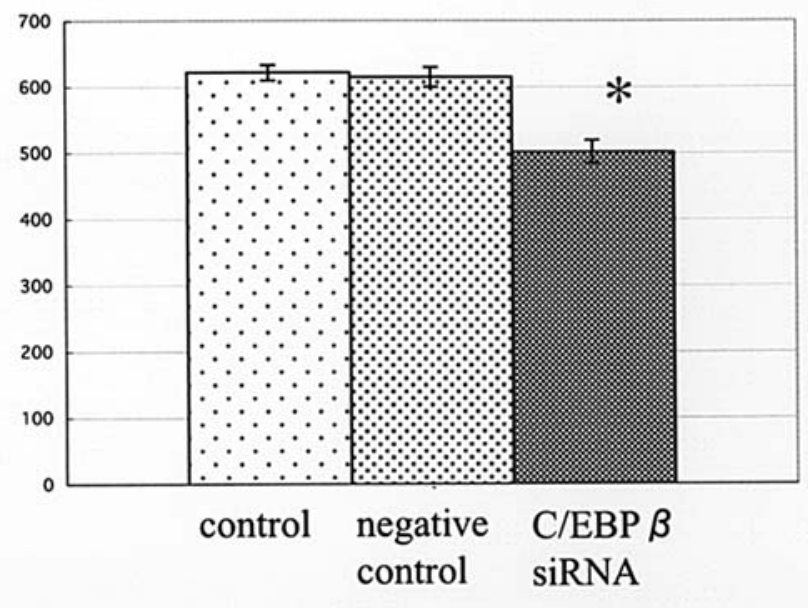

Figure 6 . IL-8 level detected in U251 cells by $100 \mathrm{IU} / \mathrm{ml}$ of IL-1 B stimulation after $24-48 \mathrm{~h}$ by ELISA. The results represent the mean $\pm \mathrm{SD}$ of cell-free culture supernatants per milliliter. IL-8 production was significantly suppressed by siRNA against C/EBP $\beta$, as reflected in the observed reduction of IL-8 production. ${ }^{*} \mathrm{P}<0.01$ compared with both control groups.
Notably, IL-6 and IL-8 are inducible by the transcription factor $\mathrm{C} / \mathrm{EBP} \beta$, and the expression of $\mathrm{C} / \mathrm{EBP} \beta$ can be stimulated by these cytokines (20). Therefore, C/EBP $B$ may play a role in the autocrine growth stimulation by IL- 6 and IL-8. IL-8, an angiogenic cytokine secreted from glioma cells, is thought to be a causative cytokine of hypervascularity in malignant glioma (23), thus contributing to the glioma progression. On the other hand, IL- 6 and IL- 8 have been suggested to have a role in cancer cell invasion by the induction of MMPs (matrix metalloproteinase) (32-34). Degradation of collagen in the extracellular matrix mediated by MMPs has been suggested to play an essential role in cancer invasion (35). Collagenase-1, belonging to a subgroup of the MMP gene family, plays an important role in collagen turnover in most human tissues (36). C/EBP B regulates MMPs expression (37) and collagenase-1 induction (38). Thus $\mathrm{C} / \mathrm{EBP} \beta$ may be related to the invasiveness of cancer.

In our study, an increased expression of $\mathrm{C} / \mathrm{EBP} \mathrm{B}$ was associated with a malignant phenotype of glioma. Therefore, the increased expression of C/EBP $\beta$ may be related to the proliferation and invasiveness of glioma. Very few mutations in C/EBP $B$ were identified in a survey of 381 cancers and 
cell lines representing leukemias, lymphomas, and various solid tumors (39). Only 2 of the 381 samples had missense mutations and 2 others had silent mutations. In contrast, 7\% of acute myeloid leukemia samples analyzed contained a mutated form of $\mathrm{C} / \mathrm{EBP} \alpha$, resulting in a truncated dominantnegative isoform or a protein with decreased DNA-binding activity (40). Therefore, unlike C/EBP $\alpha, \mathrm{C} / \mathrm{EBP} \beta$ most likely contributes to tumorigenesis through increased mRNA or protein expression rather than somatic or germline mutations. Increased C/EBP $\beta$ expression has been detected in breast cancer, ovarian tumors, colorectal tumors, and renal cell carcinoma (24-27). Conversely, C/EBP $3^{-/-}$mice were refractory to tumorigenic agents applied to the skin, implying that $\mathrm{C} / \mathrm{EBP} \mathrm{B}$ is required for tumor progression in the epidermis (41).

On the basis of our data, C/EBP $\beta$ may play a potential role in the proliferation and invasion of glioma. Thus, $\mathrm{C} / \mathrm{EBP} B$ can be a novel molecular target of therapy as well as an important predictive marker for survival in patients with glioma.

\section{Acknowledgments}

We are grateful to N. Kiyama and F. Higuchi for their excellent technical assistance.

\section{References}

1. Karpeh MS, Kelsen DP and Tepper JE: Cancer of the stomach. In: Cancer, Principles and Practice of Oncology. 6th edition. Devita VT Jr (ed). Lippincott Williams \& Wilkins, Philadelphia, pp1092-1121, 2001.

2. Stewart LA: Chemotherapy in adult high-grade glioma: a systematic review and meta-analysis of individual patient data from 12 randomized trials. Lancet 359: 1011-1018, 2002.

3. Yamanaka R, Lekstrom-Himes J, Barlow C, Wynshaw-Boris A and Xanthopoulos KG: CCAAT/enhancer binding proteins are critical components of the transcriptional regulation of hematopoiesis (Review). Int J Mol Med 1: 213-221, 1998.

4. Williams SC, Cantwell CA and Johnson PF: A family of C/ EBP-related proteins capable of forming covalently linked leucine zipper dimers in vitro. Genes Dev 5: 1553-1567, 1991.

5. Stein B, Cogswell PC and Baldwin AS Jr: Functional and physical associations between NF-kappa B and C/EBP family members: a Rel domain-bZIP interaction. Mol Cell Biol 13: 3964-3974, 1993.

6. Landschulz WH, Johnson PF, Adashi EY, Graves BJ and McKnight SL: Isolation of a recombinant copy of the gene encoding C/EBP. Genes Dev 2: 786-800, 1988.

7. Wang ND, Finegold MJ, Bradley A, Ou CN, Abdelsayed SV, Wilde MD, Taylor LR, Wilson DR and Darlington GJ: Impaired energy homeostasis in C/EBP alpha knockout mice. Science 269: 1108-1112, 1995.

8. Akira S, Isshiki H, Sugita T, Tanabe O, Kinoshita S, Nishio Y, Nakajima T, Hirano T and Kishimoto T: A nuclear factor for IL-6 expression (NF-IL6) is a member of a C/EBP family. EMBO J 9: 1897-1906, 1990.

9. Tanaka T, Akira S, Yoshida K, Umemoto M, Yoneda Y, Shirafuji N, Fujiwara H, Suematsu S, Yoshida N and Kishimoto T: Targeted disruption of the NF-IL6 gene discloses its essential role in bacteria killing and tumor cytotoxicity by macrophages. Cell 80: 353-361, 1995.

10. Roman C, Platero JS, Shuman J and Calame K: Ig/EBP-1: a ubiquitously expressed immunoglobulin enhancer binding protein that is similar to C/EBP and heterodimerizes with C/EBP. Genes Dev 4: 1404-1415, 1990.

11. Cao Z, Umek RM and McKnight SL: Regulated expression of three C/EBP isoforms during adipose conversion of 3T3-L1 cells. Genes Dev 5: 1538-1552, 1991.
12. Yamanaka R, Kim GD, Radomska HS, Lekstrom-Himes J, Smith LT, Antonson P, Tenen DG and Xanthopoulos KG: CCAAT/enhancer binding protein epsilon is preferentially upregulated during granulocytic differentiation and its functional versatility is determined by alternative use of promoters and differential splicing. Proc Natl Acad Sci USA 94: 6462-6467, 1997.

13. Yamanaka R, Barlow C, Lekstrom-Himes J, Castilla LH, Liu PP, Eckhaus M, Decker T, Wynshaw-Boris A and Xanthopoulos KG: Impaired granulopoiesis, myelodysplasia, and early lethality in CCAAT/enhancer binding protein epsilon-deficient mice. Proc Natl Acad Sci USA 94: 13187-13192, 1997.

14. Ron D and Habener JF: CHOP, a novel developmentally regulated nuclear protein that dimerizes with transcription factors C/EBP and LAP and functions as a dominant-negative inhibitor of gene transcription. Genes Dev 6: 439-453, 1992.

15. Cortes-Canteli M, Pignatelli M, Santos A and Perez-Castillo A: CCAAT/enhancer-binding protein beta plays a regulatory role in differentiation and apoptosis of neuroblastoma cells. J Biol Chem 277: 5460-5467, 2002.

16. Kinoshita $S$, Akira $S$ and Kishimoto T: A member of the C/EBP family, NF-IL6 beta, forms a heterodimer and transcriptionally synergizes with NF-IL6. Proc Natl Acad Sci USA 89: 1473-1476, 1992.

17 Ossipow V, Descombes P and Schibler U: CCAAT/enhancerbinding protein mRNA is translated into multiple proteins with different transcription activation potentials. Proc Natl Acad Sci USA 90: 8219-8223, 1993.

18. Descombes P, Chojkier M, Lichtsteiner S, Falvey E and Schibler U: LAP, a novel member of the C/EBP gene family, encodes a liver-enriched transcriptional activator protein. Genes Dev 4: 1541-1551, 1990

19. Osada S, Yamamoto H, Nishihara $T$ and Imagawa M: DNA binding specificity of the CCAAT/enhancer-binding protein transcription factor family. J Biol Chem 271: 3891-3896, 1996.

20. Akira S and Kishimoto T: NF-IL6 and NF-kappa B in cytokine gene regulation. Adv Immunol 65: 1-46, 1997.

21. Matsusaka T, Fujikawa K, Nishio Y, Mukaida N, Matsushima K, Kishimoto T and Akira S: Transcription factors NF-IL6 and NFkappa B synergistically activate transcription of the inflammatory cytokines, interleukin 6 and interleukin 8. Proc Natl Acad Sci USA 90: 10193-10197, 1993.

22. Pope RM, Leutz A and Ness SA: C/EBP beta regulation of the tumor necrosis factor alpha gene. J Clin Invest 94: 1449-1455, 1994.

23. Yamanaka R, Tanaka R, Saitoh T and Okoshi S: Cytokine gene expression on glioma cell lines and specimens. J Neurooncol 21: 243-247, 1994.

24. Zahnow CA, Younes P, Laucirica R and Rosen JM: Overexpression of C/EBPbeta-LIP, a naturally occurring, dominantnegative transcription factor, in human breast cancer. J Natl Cancer Inst 89: 1887-1891, 1997.

25. Sundfeldt K, Ivarsson K, Carlsson M, Enerback S, Janson PO, Brannstrom $\mathrm{M}$ and Hedin L: The expression of CCAAT/enhancer binding protein $(\mathrm{C} / \mathrm{EBP})$ in the human ovary in vivo: specific increase in C/EBPbeta during epithelial tumour progression. $\mathrm{Br}$ J Cancer 79: 1240-1248, 1999.

26. Rask K, Thorn M, Ponten F, Kraaz W, Sundfeldt K, Hedin L and Enerback S: Increased expression of the transcription factors CCAAT-enhancer binding protein-beta (C/EBP beta) and C/ EBPzeta (CHOP) correlate with invasiveness of human colorectal cancer. Int J Cancer 86: 337-343, 2000.

27. Oya M, Horiguchi A, Mizuno R, Marumo K and Murai M: Increased activation of CCAAT/enhancer binding protein-beta correlates with the invasiveness of renal cell carcinoma. Clin Cancer Res 9: 1021-1027, 2003.

28. Oh HS and Smart RC: Expression of CCAAT/enhancer binding proteins $(\mathrm{C} / \mathrm{EBP})$ is associated with squamous differentiation in epidermis and isolated primary keratinocytes and is altered in skin neoplasms. J Invest Dermatol 110: 939-945, 1998.

29. Tomizawa M, Saisho H and Tagawa M: Regulatory regions of growth-related genes can activate an exogenous gene of the alpha-fetoprotein promoter to a comparable degree in human hepatocellular carcinoma cells. Anticancer Res 23: 3273-3277, 2003.

30. Kleihues P, Louis DN, Scheithauer BW, Rorke LB, Reifenberger G, Burger PC and Cavenee WK: The WHO classification of tumors of the nervous system. J Neuropathol Exp Neurol 61: 215-225, 2002. 
31. Maher EA, Furnari FB, Bachoo RM, Rowitch DH, Louis DN, Cavenee WK and De Pinho RA: Malignant glioma: genetics and biology of a grave matter. Genes Dev 15: 1311-1333, 2001.

32. Bostrom PJ, Ravanti L, Reunanen N, Aaltonen V, Soderstrom KO, Kahari VM and Laato M: Expression of collagenase-3 (matrix metalloproteinase-13) in transitional-cell carcinoma of the urinary bladder. Int J Cancer 88: 417-423, 2000.

33. Hofmann A, Laue S, Rost AK, Scherbaum WA and Aust G: mRNA levels of membrane-type 1 matrix metalloproteinase (MT1-MMP), MMP-2, and MMP-9 and of their inhibitors TIMP-2 and TIMP-3 in normal thyrocytes and thyroid carcinoma cell lines. Thyroid 8: 203-214, 1998.

34. Inoue K, Slaton JW, Eve BY, Kim SJ, Perrotte P, Balbay MD, Yano S, Bar-Eli M, Radinsky R, Pettaway CA and Dinney CP: Interleukin 8 expression regulates tumorigenicity and metastases in androgen-independent prostate cancer. Clin Cancer Res 6: 2104-2119, 2000.

35. De Clerck YA, Shimada H, Taylor SM and Langley KE: Matrix metalloproteinases and their inhibitors in tumor progression. Ann NY Acad Sci 732: 222-232, 1994.

36. Jeffrey JJ: Regulation of Matrix Accumulation. Mecham RP (ed). Academic Press, New York, pp53-98, 1986.
37. Qin H, Sun Y and Benveniste EN: The transcription factors $\mathrm{Sp} 1, \mathrm{Sp} 3$, and AP-2 are required for constitutive matrix metalloproteinase-2 gene expression in astroglioma cells. J Biol Chem 274: 29130-29137, 1999.

38. Doyle GA, Pierce RA and Parks WC: Transcriptional induction of collagenase-1 in differentiated monocyte-like (U937) cells is regulated by $\mathrm{AP}-1$ and an upstream C/EBP-beta site. J Biol Chem 272: 11840-11849, 1997.

39. Vegesna V, Takeuchi S, Hofmann WK, Ikezoe T, Tavor S, Krug U, Fermin AC, Heaney A, Miller CW and Koeffler HP: C/EBP-beta, C/EBP-delta, PU.1, AML1 genes: mutational analysis in 381 samples of hematopoietic and solid malignancies. Leuk Res 26: 451-457, 2002.

40. Pabst T, Mueller BU, Zhang P, Radomska HS, Narravula S, Schnittger S, Behre G, Hiddemann W and Tenen DG: Dominantnegative mutations of CEBPA, encoding CCAAT/enhancer binding protein-alpha (C/EBPalpha), in acute myeloid leukemia. Nat Genet 27: 263-270, 2001.

41. Zhu S, Yoon K, Sterneck E, Johnson PF and Smart RC: CCAAT/ enhancer binding protein-beta is a mediator of keratinocyte survival and skin tumorigenesis involving oncogenic Ras signaling. Proc Natl Acad Sci USA 99: 207-212, 2002. 